DOI: $\square$ https://doi.org/10.15407/techned2020.04.055

\title{
MANAGEMENT OF GENERATION AND REDISTRIBUTION ELECTRIC POWER IN GRID-TIED PHOTOVOLTAIC SYSTEM OF LOCAL OBJECT
}

$\quad$ Journal
Publisher
ISSN
Issue
Pages

\author{
Tekhnichna elektrodynamika
}

Institute of Electrodynamics National Academy of Science of Ukraine 1607-7970 (print), 2218-1903 (online)

No 4, 2020 (July/August)

$55-59$

\section{Authors \\ A. Shavelkin*, I. Shvedchykova \\ Kyiv National University of Technologies and Design, \\ str. Nemirovich-Danchenko, 2, Kyiv, 01011, Ukraine, \\ e-mail: shavolkin@gmail.com \\ * ORCID ID : https://orcid.org/0000-0003-3914-0812}

\begin{abstract}
Photovoltaic grid-connected system of local object with a battery when using a grid inverter with an "open" input is presented. The expediency of the structure of the converter unit use equipped by controllers of a photoelectric battery and battery with independent (external) control and the possibility of charging the battery from the grid is substantiated. It expands the possibilities of energy generation and distribution control in the power supply system of a local object with several tariff zones using an intelligent energy management system in all operating modes including autonomous. The structure of the power control channel is developed, while it is possible to use a standard MPPT controller to control the generation of a photovoltaic battery. The simulation model of the system is developed. The simulation results are given. References 9 , figures 4 .
\end{abstract}

Key words: photovoltaic battery, converter unit, storage battery, multi-zone tariff, power control channel, autonomous operating mode. 
Received: 28.02.2020

Accepted: 24.04 .2020

Published: 26.06.2020

\section{References}

1. Shavelkin A. Structures of single-phase converter units for combined electric power supply systems with photovoltaic solar batteries. Teknichna Elektrodynamika. 2018. № 2. Pp. 39-46. (Rus) DOI:

/10.15407/techned2018.02.039

https://doi.org

2. Shavelkin A., Shvedchykova I. Multifunctional converter for single-phase combined power supply systems for local objects with a photovoltaic solar battery. Teknichna Elektrodynamika. 2018. No 5. Pp. 92-95. DOI:

https://doi.org/10.15407/techned2018.05.092

3. Set of a solar power plant "Comfortable" company "Proper power supply" (Ukr) URL: https:// prel.prom.ua/p33907801-sonyachnij-komplekt-elektrostantsiyi.html

. (accessed: 15.12.2019)

4. Dhiwaakar Purusothaman S.R., Rajesh R., Bajaj K.K., Vijayaraghavan V., Venkatesan M. Hybrid battery charging system using solar PV and utility grid. Power and Energy Systems:

Towards Sustainable Energy

Bangalore. 2014. Pp. 1-5.

DOI:

https://doi.org/10.1109/PESTSE.2014.6805275

5. Hybrid network inverter Growatt 10000 HY. (Rus) URL: https://alfa.solar/ru/gibridnyj-setevojinvertor-growatt-hybrid-10000-hy-id494.html

. (accessed: 27.12.2019)

6. ABB solar inverters. URL: https:// www.abb.com/solarinverters . (accessed: 05.01.2020)

7. Photovoltaic geographical information system. URL: https://re.jrc.ec.europa.eu/pvg tools /en / tools.html\#SA . (accessed:

25.01.2020)

8. Shynyakov Yu., Shurygin Yu., Arbatova O. Improving the energy efficiency of autonomous photovoltaic power plants. Elektronika, izmeritelnaya tekhnika, radiotekhnika i svyaz. Doklady Tomskogo gosudarstvennogo universiteta sistem upravleniya i radioelektroniki . 2010. Vol. 2. No 2(22). Pp. 102-107. (Rus).

9. Malinin G., Serebryannikov A. Tracking the maximum power point of a solar batter. Vestnik 
Chuvashskogo universiteta

. 2016. No 3. Pp. 76-93. (Rus)

$\underline{\text { PDF }}$

@ $\oplus \Theta \Theta$

This work is licensed under a Creative Commons Attribution-NonCommercial-NoDerivatives 4.0 International License 